University of South Florida

DIGITAL COMMONS

Digital Commons @ University of

@ UNIVERSITY OF SOUTH FLORIDA

South Florida

$12-2-2005$

\title{
Spectral Analysis of Ground Penetrating Radar Response to Thin Sedimentary Layers
}

Swagata Guha

University of South Florida, sguha@usf.edu

Sarah E. Kruse

University of South Florida, skruse@usf.edu

E. E. Wright

Coastal Carolina University

U. E. Kruse

University of Illinois

Follow this and additional works at: https://digitalcommons.usf.edu/gly_facpub

Part of the Geochemistry Commons, Geology Commons, and the Geophysics and Seismology Commons

\section{Scholar Commons Citation}

Guha, Swagata; Kruse, Sarah E.; Wright, E. E.; and Kruse, U. E., "Spectral Analysis of Ground Penetrating Radar Response to Thin Sedimentary Layers" (2005). Geology Faculty Publications. 7.

https://digitalcommons.usf.edu/gly_facpub/7

This Article is brought to you for free and open access by the Geology at Digital Commons @ University of South Florida. It has been accepted for inclusion in Geology Faculty Publications by an authorized administrator of Digital Commons@ University of South Florida. For more information, please contact digitalcommons@usf.edu. 


\title{
Spectral analysis of ground penetrating radar response to thin sedimentary layers
}

\author{
S. Guha, ${ }^{1}$ S. E. Kruse, ${ }^{1}$ E. E. Wright, ${ }^{2}$ and U. E. Kruse ${ }^{3}$ \\ Received 21 July 2005; revised 21 October 2005; accepted 25 October 2005; published 2 December 2005.
}

[1] Ground penetrating radar (GPR) systems utilized in studies of sedimentary deposits generate wavelengths (tens of centimeters) that are commonly much longer than the thickness of bedding (often millimeters to centimeters) within the target strata. Where this is the case, radar profiles represent interference patterns. Simple models of radar response to sequences of thin beds such as those found in coastal deposits show potentially detectable spectral shifts toward higher frequencies in radar returns. Spectral analysis of radar data over barrier beach deposits at Waites Island, South Carolina, shows that returns from packages with heavy mineral laminations are shifted toward higher frequencies relative to returns from more isolated contacts. Such spectral shifts may be useful as an indicator of finescale layering on radar profiles. Citation: Guha, S., S. E. Kruse, E. E. Wright, and U. E. Kruse (2005), Spectral analysis of ground penetrating radar response to thin sedimentary layers, Geophys. Res. Lett., 32, L23304, doi:10.1029/2005GL023933.

\section{Introduction}

[2] Ground penetrating radar (GPR) has been used extensively for stratigraphic interpretation of sedimentary depositional environments by providing information on bed geometry and internal structures within the deposits. Examples include facies analysis of fluvial and deltaic deposits [Jol and Smith, 1991; Smith and Jol, 1997], coastal deposits [Gawthorpe et al., 1993], sediment budget estimation [van Heteren et al., 1996], mapping of internal structures of sand dunes [Harari, 1996; Bristow et al., 2000], and understanding the development of coastal landforms [Nishikawa and Ito, 2000; Neal et al., 2002; Jol et al., 2003].

[3] One characteristic of GPR studies in sediments is seldom explicitly discussed-namely, that the radar wavelengths used in geological studies (tens of cms to meters) are in many settings much longer than sedimentary bed thicknesses (often mms to $\mathrm{cms}$ ). In such settings the radar response constitutes an interference pattern, in which there is not a one-to-one relationship between horizons in the radar profile and contacts between sedimentary strata. Given their frequency constraints, GPR investigations, like seismic methods, always produce a filtered version of the subsurface layering. GPR data are nevertheless often col-

\footnotetext{
USA.

${ }^{1}$ Department of Geology, University of South Florida, Tampa, Florida,

${ }^{2}$ Department of Marine Sciences, Coastal Carolina University, Conway, South Carolina, USA.

${ }^{3}$ Department of Physics, University of Illinois, Urbana, Illinois, USA.
}

Copyright 2005 by the American Geophysical Union. 0094-8276/05/2005GL023933\$05.00 lected from thin bed environments, because the interference patterns provide useful information on the attitude of layering.

[4] The term "thin bed" has different meanings in sedimentology and exploration seismology. In sedimentology, thin beds are $<30-60 \mathrm{~cm}$, very thin beds are $<5 \mathrm{~cm}$, and laminae are $<1 \mathrm{~cm}$. To reflection seismologists, "thin" refers to beds for which seismic energy reflecting from the top and from the bottom of the bed cannot be resolved as distinct returns in the record. Widess [1973] points out that the thin resolution limit for a Ricker wavelet is attained when bed thickness is $\sim 1 / 4$ of the dominant wavelength $(\lambda)$ in the presence of noise (seismic or radar) within the bed. For beds thinner than $\sim \lambda / 8$ the phase and spectrum of the reflected wavelet do not vary with bed thickness, but the amplitude decreases with decreasing bed thickness [Widess, 1973]. In this paper "thin bed" (thin layer) is defined relative to the radar wavelength.

[5] In most sedimentary environments, for GPR antenna frequencies $<\sim 500 \mathrm{MHz}$, many sedimentologically thin beds and virtually all very thin beds and laminae satisfy the wavelength thin bed criteria. Moreover, in most depositional environments, thin beds are present in repetitive sequences rather than as isolated single layers. The attributes of seismic response to repetitive sequences of thin layers have been studied [e.g., Morlet et al., 1982; Knapp, 1990]. Morlet et al. [1982] show for cyclic series of layers, seismic wavelengths that are short compared to layer thicknesses are more strongly reflected than longer wavelengths (lower frequencies). Several authors have addressed GPR response to isolated thin layers [e.g., Orlando, 2002; Bradford, 2003], but GPR waveforms generated from sequences of thin beds have received little attention to date.

[6] Here we examine whether a preferential reflection of high frequencies might be observed in practice in GPR profiles in coastal sediments. We use simple models to simulate GPR response to packages of thin layers as commonly found in coastal sands. We compare model results with radar records from laminated zones comprised of $1 \mathrm{~mm}$-thick heavy mineral-rich layers embedded in fine sand and from isolated contacts in barrier beach sediments of Waites Island, SC. The results are used to determine whether information on the presence or absence of thin layers can be extracted from the frequency characteristics of radar traces.

\section{Models of Thin Beds}

[7] Wave propagation is simulated with the finitedifference time-domain (FDTD) method [Yee, 1966]. Because we are interested only in first-order features of the radar traces, computationally efficient one-dimensional (1D) 


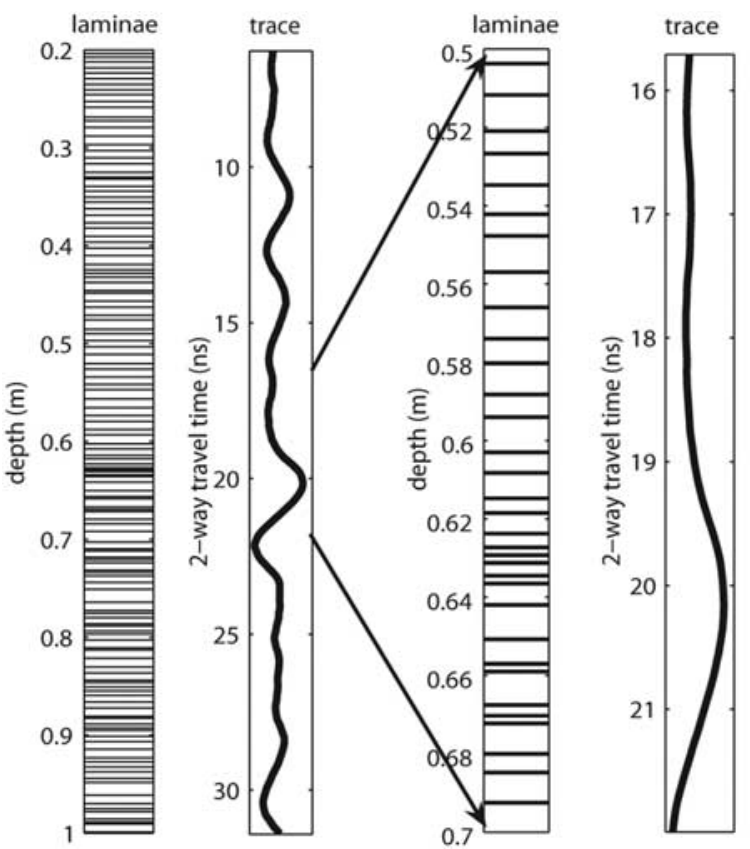

Figure 1. Example sections of 1D FDTD model and corresponding radar response. Interlayer spacing has mean $5 \mathrm{~mm}$, standard deviation $2.5 \mathrm{~mm}$. Black lines on striped columns show $1 \mathrm{~mm}$ thick layers, white is interlayer. Display of $1 \mathrm{~mm}$ layers is limited by figure resolution. Left: $80 \mathrm{~cm}$ thick section. Right: $20 \mathrm{~cm}$ thick section.

models are sufficient. The models thus assume that the signal emitted by the transmitter is a vertically-traveling plane wave tri-lobed pulse (similar to a Ricker wavelet) normally incident on contacts, with no offset between transmitter and receiver. All layers in the models are horizontal and homogeneous in nature. Model cell size is $0.25 \mathrm{~mm}$ and time step is $5 \times 10^{-4} \mathrm{~ns}$. To approximate the $1-\mathrm{mm}$ layers identified in core sediments from Waites Island, the thinnest layers modeled are also $1 \mathrm{~mm}$ (i.e. $1 / 250$ of dominant model wavelength of $25 \mathrm{~cm}$ in the layers). These individual layers are comprised of at least 4 model cells.

[8] For the models shown here, layer properties were set to values representative of saturated sands in coastal environments [Annan, 2001]. Permittivity and conductivity are assumed to be purely real. The properties of the background (interlayer) material are set to relative dielectric permittivity $\varepsilon_{r}=20$, relative magnetic permeability $\mu_{r}=1$, and conductivity $\sigma=1 \mathrm{mS} / \mathrm{m}$. These correspond to a wave velocity of $0.067 \mathrm{~m} / \mathrm{ns}$. Thin layers embedded in the background material are fixed to $\varepsilon_{r}=35, \mu_{r}=1.2$, and $\sigma=4 \mathrm{mS} / \mathrm{m}$ (velocity $=0.05 \mathrm{~m} / \mathrm{ns}$ ), which could represent a magnetite bearing heavy-mineral layer as found in coastal lag deposits. The relative permittivity for thin layers (35) is close to the value for magnetite [Schon, 1996]. For $200 \mathrm{MHz}$ frequency, the dominant wavelength within the layers is $25 \mathrm{~cm}$ and that for the interlayer spaces is $\sim 34 \mathrm{~cm}$.

\subsection{Multiple Thin Layers}

[9] Laminated zones constructed from mm-scale layers are commonly found in coastal and lacustrine depositional environments [Komar, 1976]. To better understand conditions under which such laminae could generate a significant radar response, a suite of layered models simulating beach laminations is generated. In this suite the thin layer thickness was kept constant at $1 \mathrm{~mm}$ and the interlayer spacings were varied. In each model the interlayer spacings were set to a Gaussian distribution about a fixed mean. Models were run for means of 2,5 , and $50 \mathrm{~mm}$, with standard deviations set to half of the means. The interlayer spacings were then rounded to the nearest $0.25 \mathrm{~mm}$, and set no thinner than $1 \mathrm{~mm}$. Figure 1 shows a section of a $5 \mathrm{~mm}$-mean model and the corresponding simulated GPR response. Models were run for $200 \mathrm{MHz}$ pulses as these require fewer grid cells and hence less computational time; similar results were obtained for test runs with $100 \mathrm{MHz}$ pulses [Guha, 2004].

[10] Reflection amplitudes obtained in the simulations of Gaussian laminae packages are sometimes as large as 10 or $20 \%$ of the amplitude from a single boundary of a thick bed (isolated single contact) with the same properties. Given gain settings available on commercial radar systems, such returns should be detectable in many settings. Amplitudes are higher for the models with mean interlayer spacing 5 and 50 times the lamina thickness than for mean interlayer spacing 2 times the lamina thickness. Both an increase in the ratio of interlayer spacing to layer thickness and an increase in the variability (i.e. width of the Gaussian distribution) of the interlayer spacing increase the amplitude of the reflected signal.

\subsection{Spectral Analysis of Model Traces}

[11] The spectra for the laminated package simulations were computed for tapered $240 \mathrm{~ns}$ time windows using a standard Fast Fourier Transform (fft) algorithm. The spectra, shown in Figure 2, have been averaged for three realizations of each model.

[12] Relative to the input pulse, the spectral peak is shifted $\sim 50-70 \mathrm{MHz}$ towards higher frequencies for all models (Figure 2). This shift is expected - higher frequencies "see" the thin beds and will be emphasized in the reflections - as Morlet et al. [1982] showed for cyclic layering.

[13] Such a spectral shift in portions of a trace may thus be an indicator of fine-scale ( $\mathrm{mm}$ to $\mathrm{cm}$ scale) layering within a unit. Time-frequency analysis of radar traces,

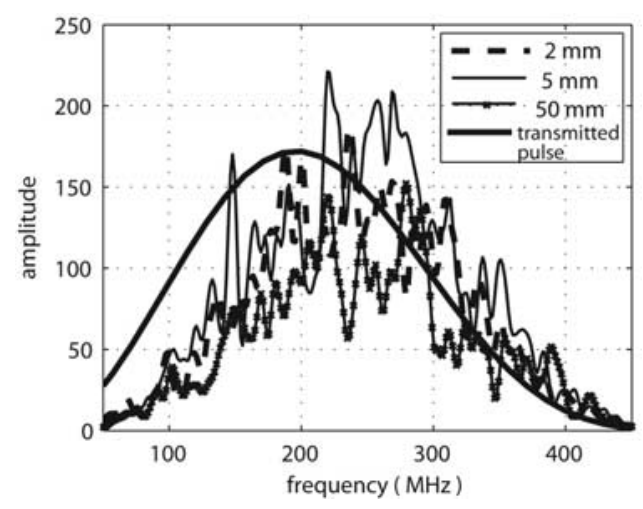

Figure 2. Spectra for 1D FDTD models of $200 \mathrm{MHz}$ GPR response to laminated zones. Model parameters given in text. Layers are all $1 \mathrm{~mm}$ thick; legend numbers give mean interlayer spacing. Interlayer thicknesses follow Gaussian distribution with standard deviation half the mean thickness. 


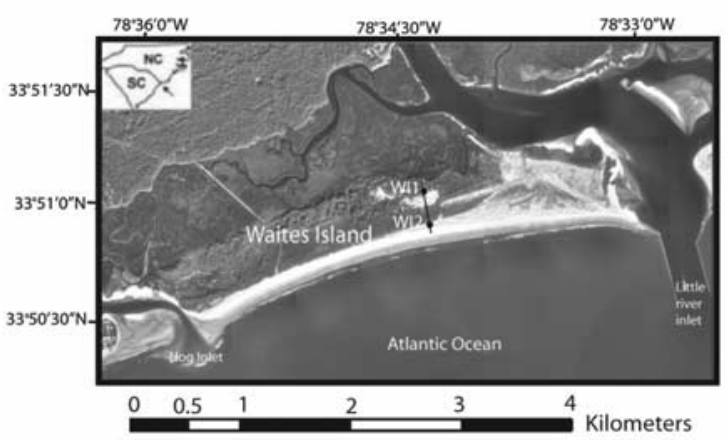

Figure 3. Location map of Waites Island, South Carolina field site. The 1994 aerial false-color photograph was provided by the GIS Data Clearinghouse of the South Carolina Dept. of Natural Resources, Land, Water, and Conservation Division.

beyond the scope of this paper, may be a fruitful indicator of laminated zones. One would expect a decrease in the typical rate of dispersion down trace (decrease in the rate of loss of higher frequencies down trace) during returns from laminated zones.

\section{Field Data: Example From Waites Island, South Carolina}

\subsection{Geologic Setting}

[14] Located on the northeastern coast of South Carolina, USA, Waites Island forms a part of the Grand Strand barrier island system (Figure 3). This $5 \mathrm{~km}$ long and $0.5 \mathrm{~km}$ wide Holocene island contains modern beach, dune, cat's eye pond, and landward marsh and tidal creek environments [Wright et al., 2001].

\subsection{Data}

[15] Reflection and common midpoint (CMP) profiles were collected with the PulseEKKO 100 system of Sensors and Software Inc. All data were dewowed; an AGC gain was applied to the profiles in Figure 4, an exponential gain to traces for spectral analysis. Profiles were ground-truthed with vibracores at sites WI1 and WI2 (Figures 3 and 4). These sites share the same surface sands exposed and hence are expected to support similar antenna radiation patterns. CMP gathers at both sites yield average velocities of $0.12 \mathrm{~m} / \mathrm{ns}$ in the unsaturated zone and $0.07 \mathrm{~m} / \mathrm{ns}$ in the saturated zone [Guha, 2004]. These two sites permit a comparison of reflections from more isolated contacts (thicker beds) at WI1 with the reflections from a laminated section at WI2.

[16] Core sediments at site WI1 show a zone of mm-thick magnetite-rich laminations above the water table, but below the water table laminations are absent. The dominant features are a $15 \mathrm{~cm}$ thick marsh mud layer within sands, underlain by an $80 \mathrm{~cm}$ marsh mud layer. The $100 \mathrm{MHz}$ reflection profile at site WI1 (Figure 4) shows a prominent reflection (R2) from the sharp upper boundary of the lower marsh mud layer. For comparison, core sediments at site WI2 reveal mm-thick magnetite-rich beach laminations separated by $\mathrm{mm}$ to $\mathrm{cm}$-scale interlayers over a depth range from $\sim 0.6$ to 4 meters.

[17] Because of the similarity in the surface sands, we expect the pulses from the transmitter that reach the layers

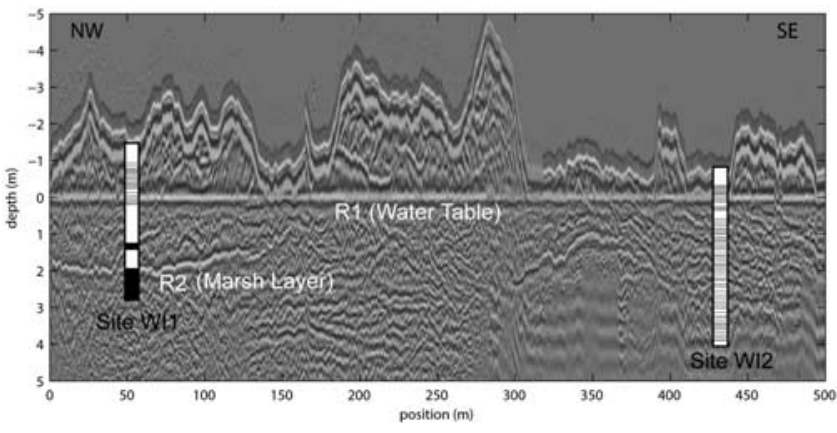

Figure 4. $100 \mathrm{MHz}$ GPR profile (see Figure 3 for location) and core schematics. At WI1 and WI2 thin lines on core columns indicate magnetite-rich laminae; at WI1 thicker black zones show marsh mud layers. Velocities assumed to be $0.12 \mathrm{~m} / \mathrm{ns}$ in above water table, $0.07 \mathrm{~m} / \mathrm{ns}$ below water table.

to be spectrally similar in both the settings. The models above predict a spectral shift to higher frequencies in returns from the laminated zone at WI2 relative to that from the thicker zones at WI1.

\subsection{Spectral Analysis of GPR Traces}

[18] Figure 5 shows a comparison of the spectra from the laminated zone at WI2, and from the thicker units at WI1. At both sites spectra were computed over tapered $100 \mathrm{~ns}$ windows that extend from just below the water table downward $\sim 3.5 \mathrm{~m}$ into the saturated zone. For each site spectra were computed for 10 adjacent traces; 10-spectra averages are shown in Figure 5. The GPR response to the WI2 laminated zone shows spectral peaks shifted upward $\sim 40-50 \mathrm{MHz}$ relative to those from the thicker bed WI1 zone. The shift is similar in magnitude to that predicted by the thin layer models (Figure 2) (although the models were run for $200 \mathrm{MHz}$ center frequencies).

[19] We note that one might expect higher peak frequencies at site WI2 simply because the spectra represent an earlier time window, as the unsaturated zone is thinner there. Dispersive loss of higher frequencies as a part of intrinsic attenuation is common in geologic media [e.g., Irving and Knight, 2003]. Additionally, frequency dependent reflection, due to frequency dependent material prop-

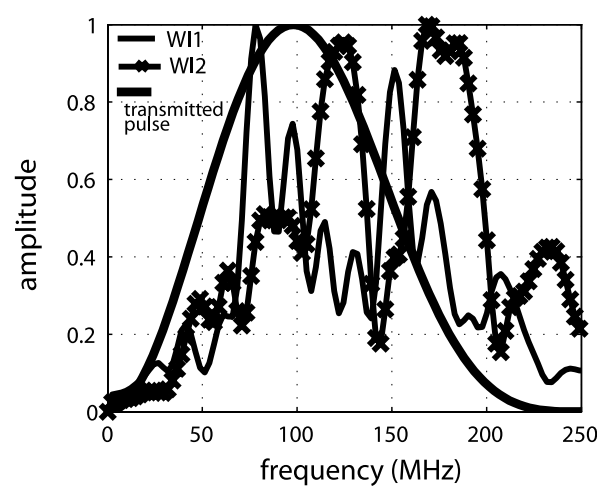

Figure 5. Spectra for GPR traces from below water table to $\sim 3.5 \mathrm{~m}$ depth at sites WI1 and WI2 (Figure 4). See text for details. 
erties can be significant and can cause the spectrum to shift to either higher or lower frequencies. While these effects may be small in some cases compared to the thin layer effect, in other cases they may dominate. Further analyses are needed to evaluate the relative magnitude of these effects in sedimentary strata.

\section{Conclusions}

[20] Thin beds are very common in GPR surveys in sediments, but extracting information on thin beds from GPR profiles has not been widely discussed. From simple models of radar wave propagation, and comparative analysis of GPR records and core sediment records from a sandy barrier island, the following conclusions are drawn:

[21] 1) Modeling shows that the presence of multiple thin beds, such as magnetite-enriched laminae in coastal sedimentary deposits, can produce low amplitude but detectable GPR returns at the commonly used frequencies of 100 to $500 \mathrm{MHz}$. The returns cannot be directly correlated with individual laminations. Return amplitudes will depend on the distribution of layer thicknesses and background interlayer spacings.

[22] 2) Spectral analysis of both model and real traces indicate that the presence of $\mathrm{mm}$-scale laminations is accompanied by a spectral shift towards higher frequencies. Spectral shifts may thus serve as an indicator of local zones of thin beds.

[23] 3) Comparison of observations with models based on contacts seen in cores in Waites Island, SC, suggests that $\mathrm{mm}$-scale magnetite-rich laminae, although well below the thin bed limit, are an important contributor to the radar signal.

[24] Acknowledgments. We are grateful to Danya Pase and M. Scott Harris for help in field data acquisition. The GPR collection was supported by the USGS-South Carolina Sea Grant Consortium (SC Sea Grant number Q46G). Constructive comments from two anonymous reviewers significantly improved the manuscript.

\section{References}

Annan, A. P. (2001), Ground penetrating radar workshop notes, Sensors and Software, Mississauga, Ont., Canada.

Bradford, J. H. (2003), GPR offset dependent reflectivity analysis for characterization of a high-conductivity LNAPL plume, paper presented at SAGEEP 2003 Symposium on the Application of Geophysics to Environmental and Engineering Problems, Environ. and Eng. Geophys. Soc. San Antonio, Tex.

Bristow, C. S., S. D. Bailey, and N. Lancaster (2000), The sedimentary structure of linear sand dunes, Nature, 406(6791), 56-59.

Gawthorpe, R. L., R. E. L. Collier, J. Alexander, J. S. Bridge, and M. R. Leeder (1993), Ground penetrating radar: Application to sandybody geo- metry and heterogeneity studies, in Characterization of Fluvial and Aeolian Reservoirs, edited by C. P. North and D. J. Prosser, Geol. Soc. Spec. Publ., 73, 421-432.

Guha, S. (2004), Ground penetrating radar response to thin layers: Examples from Waites Island, South Carolina, M.S. thesis, Univ. of S. Fla., Tampa.

Harari, Z. (1996), Ground Penetrating Radar (GPR) for imaging stratigraphic features and groundwater in sand dunes, J. Appl. Geophys., $36(1), 43-52$

Irving, J. D., and R. J. Knight (2003), Removal of wavelet dispersion from ground-penetrating radar data, Geophysics, 68(3), 960-970.

Jol, H. M., and D. G. Smith (1991), Ground penetrating radar of northern lacustrine deltas, Can. J. Earth Sci., 28, 1939-1947.

Jol, H., D. C. Lawton, and D. G. Smith (2003), Ground penetrating radar: 2-D and 3-D subsurface imaging of a coastal barrier spit, Long Beach, WA, USA, Geomorpholoy, 53, 165-181.

Knapp, R. W. (1990), Vertical resolution of thick beds, thin beds and thinbed cyclothems, Geophysics, 65, 1183-1190.

Komar, P. D. (1976), Beach Processses and Sedimentation, Prentice-Hall, Upper Saddle River, N. J.

Morlet, J., G. Arens, E. Fourgeau, and D. Giard (1982), Wave propagation and sampling theory-part I: Complex signal and scattering in multilayered media, Geophysics, 47(2), 203-221.

Neal, A., N. I. Pontee, K. Pye, and J. Richards (2002), Internal structure of mixed-sand-and-gravel beach deposits revealed using ground-penetrating radar, Sedimentology, 49, 789-804.

Nishikawa, T., and M. Ito (2000), Late Pleistocene barrier-island development reconstructed from genetic classification and timing of erosional surfaces, paleo-Tokyo Bay, Japan, Sediment. Geol., 137, 25-42.

Orlando, L. (2002), Detection and analysis of LNAPL using the instantaneous amplitude and frequency of ground-penetrating radar data, Geophys. Prospect., 50, 27-41.

Schon, J. H. (1996), Physical properties of rocks: Fundamentals and principles of petrophysics, in Handbook of Geophysical Exploration, edited by K. T. Helbig, 583 pp., Elsevier, New York.

Smith, D. G., and H. M. Jol (1997), Radar structure of Gilbert-type delta, Peyto Lake, Banff National Park, Canada, Sediment. Geol., 113, 195209.

van Heteren, S., D. M. FitzGerald, D. C. Barber, J. T. Kelley, and D. F. Belknap (1996), Volumetric analysis of a New England barrier system using ground-penetrating-radar and coring techniques, J. Geol., 104, $471-483$.

Widess, M. B. (1973), How thin is a thin bed?, Geophysics, 38(6), 11761180 .

Wright, E., M. S. Harries, A. Sapp, K. Lewis, S. Kruse, and N. T. Edgar (2001), Stratigraphic development of a northeastern South Carolina barrier island, Waites Island, Geol. Soc. Am. Abstr. Programs, 36(3), 193.

Yee, K. S. (1966), Numerical solution of initial boundary problems involving Maxwell's equations in isotropic media, IEEE Trans. Antennas Propag., 14, 302-309.

S. Guha and S. E. Kruse, Department of Geology, University of South Florida, 4202 East Fowler Avenue, Tampa, FL 33620, USA. (sguha@, mail.usf.edu)

U. E. Kruse, Department of Physics, University of Illinois, Urbana, IL 61801, USA.

E. E. Wright, Department of Marine Sciences, Coastal Carolina University, Conway, SC 29528, USA. 